\title{
COURSE REVIEW HORAY (CRH) LEARNING MODEL TO IMPROVE MATHEMATICAL LEARNING OUTCOMES OF INTEGERS MATERIALS
}

\author{
Hery Setiyawan $^{1}, *$ Abdillah $^{2}$ \\ ${ }^{1}$ Universitas Wijaya Kusuma Surabaya \\ ${ }^{2}$ IAIN Ambon \\ ${ }^{1}$ Hery_deathschyte@yahoo.co.id \\ 2abdillah@iainambon.ac.id (CA)
}

\begin{abstract}
Abstrak
Salah satu masalah pada proses pembelajaran kelas V SD Al-Manar Surabaya tahun ajaran 2019-2020 materi bilangan bulat adalah guru menggunakan metode ceramah yang membuat siswa cepat bosan dan pasif. Dampaknya adalah siswa sulit menerima pelajaran dengan baik dan hasil belajar kurang dari KKM. Oleh karena itu, untuk mengatasi masalah tersebut peneliti menerapkan model pembelajaran course review horay $(\mathrm{CRH})$. $\mathrm{CRH}$ dapat membuat siswa lebih aktif dan tidak merasa bosan. Disamping itu, penerapan model pembelajaran course review horay ini dapat memfokuskan siswa dalam pembelajaran, sehingga siswa akan lebih mudah menerima materi dengan baik. Tujuan penelitian ini ialah mendeskripsikan adanya peningkatan hasil belajar setelah diterapkan model pembelajaran course review horay $(\mathrm{CRH})$ mata pelajaran matematika materi bilangan bulat pada siswa kelas $\mathrm{V}$ SD Al-Manar Surabaya. Jenis penelitian ini adalah penelitian tindakan kelas yang telah dilaksanakan sebanyak dua siklus dengan indikator keberhasilan penelitian sebesar 75\%. Subyek penelitian ini ialah siswa kelas V-B SD AlManar Surabaya yang berjumlah 28 siswa, terdiri dari 14 siswa laki-laki dan 14 siswa perempuan. Hasil penelitian menunjukkan bahwa hasil belajar mengalami peningkatan dengan persentase ketuntasan siklus I 64,28\% dan siklus II $85,71 \%$. Dengan demikian dapat disimpulkan bahwa model pembelajaran course review horay $(\mathrm{CRH})$ dapat meningkatkan hasil belajar matematika materi bilangan bulat pada siswa kelas V SD Al-Manar Surabaya. Kata kunci: CRH, hasil belajar, dan bilangan bulat
\end{abstract}

\begin{abstract}
One of the problems in the learning process of class V SD Al-Manar Surabaya in the academic year 2019-2020 integer material is the teacher uses lecture methods that make students quickly bored and passive. The impact is students have difficulty accepting lessons well and learning outcomes are less than KKM. Therefore, to overcome these problems the researchers applied the course review horay $(\mathrm{CRH})$ learning model. $\mathrm{CRH}$ can make students more active and not feel bored. In addition, the application of the course review horay learning model can focus students in learning, so students will more easily receive the material well. The purpose of this study is to describe an increase in learning outcomes after applying the course review horay $(\mathrm{CRH})$ learning model of mathematics in integer material in fifth grade students of SD Al-Manar Surabaya. This type of research is a classroom action research that has been carried out in two cycles with an indicator of research success by $75 \%$. The subjects of this study were 28 students in grade V-B SD Al-Manar Surabaya, consisting of 14 male students and 14 female students. The results showed that learning outcomes have increased with the percentage of completeness of the first cycle $64.28 \%$ and the second cycle $85.71 \%$. Thus it
\end{abstract}


can be concluded that the course review horay $(\mathrm{CRH})$ learning model can improve mathematics learning outcomes of integer material in fifth grade students of SD Al-Manar Surabaya.

Keywords: CRH, learning outcomes, integer

Citation: Setiyawan, H., Abdillah. 2019. Course Review Horay (CRH) Learning Model to Improve Mathematical Learning Outcomes of Integers Materials. Matematika dan Pembelajaran, 7(2), 31-41. DOI: http://dx.doi.org/10.33477/mp.v6i2

\section{PRELIMINARY}

Education is an important means to improve the quality of human resources (HR) in ensuring the sustainable development of a nation. Improving the quality of human resources is far more urgent to be realized, especially in the face of the era of global competition (Suwartini, 2017) (Rusmini, 2017) (NASIONAL, 2014). Therefore, improving the quality of human resources from an early age is an important thing that must be seriously considered. If education is one of the main instruments for human resource development, educators in this case the teacher as one of the elements that play an important role in it, has the responsibility to develop tasks and overcome all problems that arise (Hasyim, 2014) (Asmadawati, 2014). Thus the teacher is an important component in the learning process in the classroom as not micro-educational success.

One of the teacher's strategic steps to support the success of student learning is the effort to think of a learning model that suits students' conditions. The selection of the right learning model will support students' success in learning (Wibowo, 2016).

Often found in the classes of a school so far is learning that is only centered on the teacher (Scristia, Hiltrimartin, \& Santoso, 2018). Where the teacher only gives material using the lecture method and the assignment method (Taufik \& Suryanti, 2018). The use of the lecture method and the assignment method cause low student participation, slow student progress, student attention and interest cannot be monitored (Ranti, 2016). This has resulted in student learning outcomes can not be optimal. Whereas at this time students are required to understand the learning material that is not small, even though the material is difficult to understand. Therefore, it is the teacher's job to deliver learning that is easily 
understood by students through the learning model as a means of facilitating communication.

Similar problems occur especially in students in the fifth grade -B SD AlManar Surabaya, in accordance with an interview that was held on March 24, 2019, the teacher said that so far the material was explained using only lecture and assignment methods. That was caused by the limited time available, while the material presented was quite a lot. These problems are causing the learning outcomes of students in the fifth grade-B SD Al-Manar to be low seen from student learning outcomes in mathematics subject matter of integers who reach the minimum completeness requirement (KKM) student learning outcomes of $43.25 \%$.

Such conditions are due to the nature of the material in the form of facts and concepts, which are not easily remembered by students. Knowledge that is dominated by facts and data is not easy to teach using lecture and assignment methods, because the instructor himself will find it difficult to remember all of the material and students will quickly get bored, even learning goals may fail because of the low student learning outcomes.

One type of learning model that is appropriate in the material is to use a course review horay $(\mathrm{CRH})$ learning model. With this learning model students will easily understand and easily remember integer material, because in the course review horay learning model students are invited to recall the learning of integer material that has been learned by means of groups and given questions from the teacher then shouted the word 'hooray !!' with the group that makes students become enthusiastic in the learning process.

Seeing this situation, researchers sought to improve student learning outcomes in mathematics by using the Course Review Horay (CRH) learning model which is inseparable from the lecture method but the authors suggest using the Course Review Horay (CRH) method is one of the innovative learning models that makes active and creative students in learning. So, the course review horay (CRH) model is a model that leads students to cooperative learning that can change the atmosphere of learning to be meaningful and fun, in accordance with students' thinking abilities that can improve student learning outcomes. Based on the description above, this study aims to describe the increase in mathematics learning 
outcomes of integer material in fifth grade students in SD Al-Manar Surabaya after applying the course review horay learning model.

\section{COURSE REVIEW HORAY (CRH) LEARNING MODEL}

Course review horay $(\mathrm{CRH})$ learning model is one of cooperative learning, namely teaching and learning activities by grouping students into small groups. According to (Huda, 2013) the course review horay (CRH) learning model is a learning method that can create a lively and fun classroom atmosphere because every student who can answer correctly is required to shout "hooray !!" or other yells that are liked. This method tries to test students' understanding in answering questions, where the answers to the questions are written on a card or box that has a number. Students or groups who give the correct answer should immediately shout 'hooray !!' or sing their group yells. This method also helps students to understand concepts well through group discussions. In the horay review course (CRH) learning, students are divided into groups and each student gets a numbered card. Then the teacher gives questions and students answer according to the numbers mentioned. If the answer is correct then the whole group shouts 'hooray !!'.

Steps for Course Review Horay (CRH) Learning Model Steps for Course Review Horay (CRH) learning model, as follows:

1. The teacher conveys competency material to be achieved;

2. The teacher presents or demonstrates the material according to the topic with questions and answers;

3. The teacher divides students into groups;

4. To test understanding, students are asked to make cards or boxes as needed. The card or box is then filled in with the number specified by the teacher;

5. The teacher reads the questions randomly and the students write their answers on a card or box whose number the teacher mentions;

6. After reading the questions and answers of students written on cards or boxes, the teacher and students discuss the questions that have been given;

7. For questions that are answered correctly, students give a check list $(\sqrt{ })$ and immediately shout 'hooray !!; 
8. Student grades are calculated from correct answers and many who shout berteriakhooray !! ';

9. The teacher gives rewards to the group that gets the highest score or who most often gets 'hooray !!'.

\section{LEARNING OUTCOMES}

According to (Susanto, 2014) learning outcomes are changes that occur in students, both concerning cognitive, affective and psychomotor aspects as a result of learning activities. The understanding of learning outcomes as outlined above is emphasized again by Nawawi (in (Susanto, 2014)) learning outcomes can be interpreted as the level of student success in learning subject matter at school which is stated in the scores obtained from the test results in knowing a number of specific subject matter.

According to (Sudjana, 2014) assessment of learning outcomes is the process of assigning grades to learning outcomes that have been achieved by students with certain criteria. That way, the object of assessment is student learning outcomes. The essence of assessment is the process of assigning or determining values to certain objects based on certain criteria. Characteristics of assessment are the existence of the object or program being assessed and the existence of criteria as a basis for comparing reality or what is with the criteria or what should be. Learning outcomes taken in this study only cover students' cognitive abilities. Student cognitive learning outcomes are taken from the results of tests given after learning.

\section{RESEARCH METHODS}

This type of research is Classroom Action Research (CAR) which is designed to help teachers know what is really happening in the classroom, this information is useful for making the right decision to determine the learning model that should be used in teaching and learning, for the sake of increasing teacher professionalism, learning achievement, class and school. According (Wardhani \& Wihardit, 2013) research conducted by teachers in their own classes through self-reflection, with the aim to improve performance as a teacher, so that student learning outcomes are improved. 
The subjects in this study were students in fifth grade-B SD Al-Manar Surabaya in the academic year 2019-2020 with a total of 28 students. Consisting of 14 male students and 14 female students. Data collection in this study was carried out by test technique. The learning achievement test is used to collect data about increasing student learning outcomes in integer material by looking at the test scores obtained by students in fifth grade-B SD Al-Manar Surabaya. The test is also one of a series of activities in the application of learning using the course review horay (CRH) learning model. The test in question is a written test. This written test took the form of a description of 10 questions. This test score is also used as a determinant of increasing student learning outcomes in integer material so that it can determine the increase in learning outcomes and student activity in fifth gradeB SD Al-Manar by using the course review horay (CRH) learning model.

The study using the course review horay $(\mathrm{CRH})$ learning model was declared successful, if the level of student learning outcomes in mathematics learning integer material through the course review horay $(\mathrm{CRH})$ learning model of students in the fifth grade elementary school Al-Manar Surabaya, was declared successful if $\geq 75 \%$ of students reach minimum completeness criteria.

\section{RESEARCH RESULTS AND DISCUSSION}

The results of this class action research include an increase in student learning outcomes in fifth grade-B SD Al-Manar Surabaya integer material after the course review horay $(\mathrm{CRH})$ learning model is applied. Classroom action research (CAR) is carried out in two cycles, for each cycle four main activities are carried out in accordance with the research design used, including planning, implementing, observing, and reflecting. Research data collected in this study are student learning outcomes.

The results of the first cycle learning test were obtained by students after working on individual learning outcomes assessment sheets. From the research results known that the number of students who have completed grades is 18 students and those who have not completed grades are 10 students, with a percentage of completeness of $64.28 \%$. This shows that the percentage of completeness of student learning outcomes is relatively high and can not be said to be successful because it 
is less than the indicator of mastery success of student learning outcomes that is $\geq$ $75 \%$.

Based on the reflections that have been made, the deficiencies found in the implementation of learning cycle I are explained as follows:

1. In the learning process, the teacher lacks mastery of the class, so there are still students who make noise in the classroom.

2. The teacher pays little attention to the time of class, so that the learning time increases for approximately 15 minutes.

3. The division of student groups is too much and not very attractive, so students find it difficult to find the group by finding the same number causing noise.

4. There are too many group divisions, so that fewer group members and students also get fewer questions, so the questions for the course review horay $(\mathrm{CRH})$ learning model are also small

Based on the explanation of the shortcomings of the first cycle of classroom action research, there are things that need to be improved to improve the learning process in the next cycle, which are as follows:

1. The teacher increases guidance and attention to all students, so that if there are students who do not pay attention when explaining the material the teacher can reprimand it.

2. Teachers pay more attention to learning time, so the teacher can manage lesson time well

3. The group division will be grouped into 4 groups with 7 student members. In addition, the cards for the course review horay (CRH) learning model will be replaced using colored cards (folding paper) so that the division of groups will also be easier for students to do and reduce noise.

4. The fewer group divisions, the more group members there will be more questions on the course review horay $(\mathrm{CRH})$ learning model more and more

The results of learning tests obtained by cycle 2 students revealed that the number of students who received a total score of 24 students and those who received an incomplete score of 4 students, with a percentage of completeness of $85.71 \%$. This shows that the percentage of mastery learning outcomes of students is 
classified as very high and can be said to be successful because it exceeds the indicators of mastery success of student learning outcomes that is $\geq 75 \%$.

Based on the percentage of mastery learning outcomes in the first cycle and second cycle can be stated that the first cycle to the second cycle increased by $21.43 \%$. The percentage increase can be seen in the diagram below.

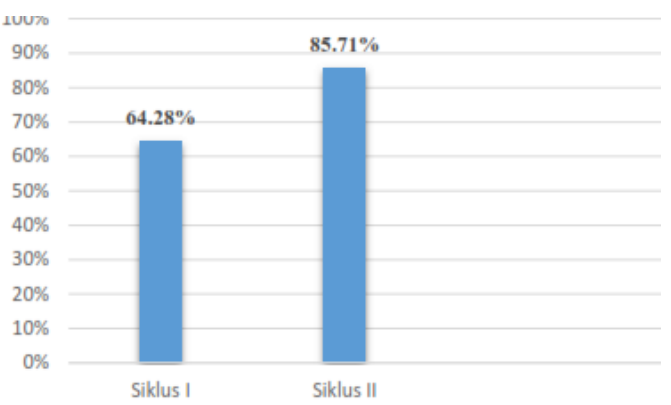

Figur 1. The graph of student learning outcomes in the cycle I and cycle II

Improved student learning outcomes occur because in the $\mathrm{CRH}$ learning process, students are required to be more active both physically and mentally, as well as cognitive, affective and psychomotor in learning activities. CRH creates a lively and pleasant classroom atmosphere because every student who can answer correctly is required to shout "hooray !!" or the scream is an expression that is liked by students (Dewi, Pudjawan, \& Kusmariyatni, 2016) (Mediatati \& Suryaningsih, 2016), while the teacher only acts as a facilitator who provides help as needed (Lestari, Sudarma, \& Japa, 2016). (Aris, 2014) stated that, "The CRH learning model is one part of cooperative learning, namely teaching and learning activities by grouping students into small groups". Other than that (Kurniasih \& Berlin, 2015) stated that, "The $\mathrm{CRH}$ learning model is a learning model that can create a lively and fun classroom atmosphere because every student who can answer correctly then the student is required to shout" hooray! ".

CRH stages are students asked to make cards or boxes as needed. The card or box is then filled in with the number specified by the teacher. The teacher randomly reads the questions and students write their answers on a card or box whose number is mentioned by the teacher. After reading students' questions and answers written on cards or boxes, the teacher and students discuss the questions that have been given. For questions that are answered correctly, students provide a checklist $(\sqrt{ })$ 
and immediately shout "hooray". Student grades are calculated from correct answers and many shout "hooray"; The teacher gives a gift to the group that gets the highest score or who gets the most "hooray" on CRH learning requires students to identify problems, design individual problem solving and collaborate in groups and test student understanding (Mediatati \& Suryaningsih, 2016). This CRH learning model encourages students to play an active role in working together in learning and remains in the teacher's guidance for the effectiveness of the learning process (Lestari, Sudarma, \& Japa, 2016). Working together in a learning community can build deep knowledge, through debate on a topic, so students can evaluate, ask questions, sharpen, or build ideas from their peers (Pratiwi, Ardianti, \& Kanzunnudin, 2018). The advantage of the CRH model is that the learning process is interesting and can encourage students to be active in the learning process because learning is not monotonous because it is interspersed with a little entertainment so the atmosphere is not tense. In addition students are more enthusiastic about learning because the learning atmosphere is fun and can practice collaboration.

\section{CONCLUSIONS AND SUGGESTIONS}

Based on the research objectives, data analysis and discussion of research results it can be concluded that the application of the course review horay $(\mathrm{CRH})$ learning model can improve student learning outcomes in fifth grade material in AlManar Elementary School Surabaya from cycle I reaching $64.28 \%$ to cycle II reached $85.71 \%$ so there was an increase of $21.43 \%$.

Based on the results of research and discussion that have been described, there are a number of suggestions which are later expected to be able to help improve student learning outcomes in the fifth grade SD Al-Manar Surabaya better. Among these suggestions, the researcher added insight into the learning model and became a reference that the learning process was not only focused on textbooks and blackboards but instead used a learning model. Improving student learning outcomes by using the course review horay $(\mathrm{CRH})$ learning model can be used as a basis for consideration for designing further learning activities. 
References

Aris, S. (2014). 68 Model Pembelajaran Inovatif Dalam Kurikulum 2013. Yogyakarta: Arruzz Media.

Asmadawati. (2014). PERENCANAAN PENGAJARAN. Jurnal Darul 'Ilmi, 02(01), 1-13.

Dewi, N. P., Pudjawan, K., \& Kusmariyatni, N. (2016). PENGARUH CRH BERBANTUAN MEDIA QUESTION CARDS TERHADAP HASIL BELAJAR MATEMATIKA SISWA KELAS IV SD. e-Journal PGSD Universitas Pendidikan Ganesha Jurusan PGSD, 4(1), 1-11.

Hasyim, M. (2014). PENERAPAN FUNGSI GURU DALAM PROSES PEMBELAJARAN.

AULADUNA, 1(2), 265-276.

Huda, M. (2013). Model-Model Pengajaran Dan Pembelajaran. Yogyakarta: Pustaka Pelajar.

Kurniasih, I., \& Berlin. (2015). Ragam Pengembangan Model Pembelajaran Untuk Peningkatan Profesionalitas Guru. Jakarta: Kata Pena.

Lestari, N. A., Sudarma, I. K., \& Japa, I. G. (2016). IMPLEMENTASI MODEL PEMBELAJARAN COURSE REVIEW HORAY UNTUK MENINGKATKAN AKTIVITAS DAN HASIL BELAJAR IPA DI SD. e-Journal PGSD Universitas Pendidikan Ganesha Jurusan PGSD, 4(1), 1-9.

Mediatati, N., \& Suryaningsih, I. (2016). Penggunaan Model Pembelajaran Course Review Horay dengan Media Flipchart Sebagai Upaya Meningkatkan Hasil Belajar PKn. Jurnal Ilmiah Sekolah Dasar, 1(2), 113-121.

NASIONAL, B. I. (2014). RENCANA PEMBANGUNAN JANGKA MENENGAH NASIONAL 2015-2019. Jakarta: KEMENTERIAN PERENCANAAN PEMBANGUNAN NASIONAL/BADAN PERENCANAAN PEMBANGUNAN NASIONAL.

Pratiwi, I. A., Ardianti, S. D., \& Kanzunnudin, M. (2018). PENINGKATAN KEMAMPUAN KERJASAMA MELALUI MODEL PROJECT BASED LEARNING (PjBL) BERBANTUAN METODE EDUTAINMENT PADA MATA PELAJARAN ILMU PENGETAHUAN SOSIAL. JURNAL REFLEKSI EDUKATIKA, 8(2), 177-182.

Ranti, M. G. (2016). PARTISIPASI SISWA PADA PEMBELAJARAN MATEMATIKA SMA MENGGUNAKAN PENDEKATAN CTL (CONTEXTUAL TEACHING AND LEARNING). Math Didactic: Jurnal Pendidikan Matematika, 2(1), 41-46.

Rusmini. (2017). PENINGKATAN MUTU SUMBER DAYA MANUSIA MELALUI PENDIDIKAN KARAKTER DAN ATTITUDE. Nur El-Islam, 4(2), 79-96.

Scristia, Hiltrimartin, C., \& Santoso, B. (2018). Analisis konsepsi guru-guru matematika Sekolah Menengah tentang hakikat masalah matematika dalam Pembelajaran 
Matematika di SMA kota Palembang. Jurnal Pendidikan Matematika, 12(1), 7988.

Sudjana, N. (2014). Penilaian Hasil Proses Belajar Mengajar. Bandung: PT. Remaja Rosdakarya.

Susanto, A. (2014). Teori Belajar dan Pembelajaran di Sekolah Dasar. Jakarta: Kencana Prenadamedia Group.

Suwartini, S. (2017). PENDIDIKAN KARAKTER DAN PEMBANGUNAN SUMBER DAYA MANUSIA KEBERLANJUTAN. Trihayu: Jurnal Pendidikan Ke-SD-an, 4(1), 220-234.

Taufik, A., \& Suryanti. (2018). Efektivitas penerapan metode pembelajaran Hypnoteaching terhadap hasil belajar matematika. Histogram: Jurnal Pendidikan Matematika, 2(2), 183-194.

Wardhani, I., \& Wihardit, K. (2013). Penelitian Tindakan Kelas. Tangerang Selatan: Universitas Terbuka.

Wibowo, N. (2016). UPAYA PENINGKATAN KEAKTIFAN SISWA MELALUI PEMBELAJARAN BERDASARKAN GAYA BELAJAR DI SMK NEGERI 1 SAPTOSARI. Jurnal Electronics, Informatics, and Vocational Education (ELINVO), 1(2), 128-139. 